\title{
KADAR MILK UREA NITROGEN (MUN) PADA SAPI PERANAKAN FRIESIAN HOLSTEIN (PFH) BERDASARKAN CALVING INTERVAL YANG BERBEDA
}

\section{MILK UREA NITROGEN (MUN) LEVEL ON FRIESIAN HOLSTEIN CROSSBREED BASED ON DIFFERENT CALVING INTERVAL}

\author{
Hanif Sabekti Pratama ${ }^{1)}$, *Imam Mustofa ${ }^{2)}$, Widya Paramita Lokapirnasari ${ }^{3)}$ \\ Pudji Srianto $^{2)}$, Rimayanti ${ }^{2)}$, Suzanita Utama ${ }^{2}$ \\ ${ }^{1)}$ Student, ${ }^{2)}$ VeterinaryReproduction Department, ${ }^{3)}$ Animal Husbandry Department \\ Faculty of Veterinary Medicine, Universitas Airlangga \\ hanifsabekti@gmail.com; *Corresponding author: email: imam.mustofa@ymail.com
}

\begin{abstract}
Milk urea nitrogen (MUN) analys may be used as a signal potential problem in feeding program. The aim of this research was to know levels of milk urea nitrogen with different calving interval. This research was using purposive sampling in KUD Tani Wilis, Sendang, Tulungagung. The sample was obtained from breeder as much as 16 samples, grouped into 2 groups, group 1 calving interval $\leq 370$ and group 2 calving interval $\geq 450$. This samples tested in Surabaya laboratory of health (Balai Besar Laboratorium Kesehatan Surabaya). The result showed that MUN not signifcanly different with different calving interval $(\mathrm{p}>0,05)$. The conclusion of this research was MUN did not related with different calving interval.
\end{abstract}

Keywords : Friesian Holstein, Milk Urea Nitrogen, Milk, Calving Interval

Pendahuluan

Kebutuhan susu di Indonesia terus meningkat seiring dengan terus meningkatnya pertumbuhan penduduk. Produksi susu dalam negeri belum mampu memenuhi kebutuhan nasional, pada tahun 2014 lebih dari 80\% kebutuhan susu nasional dipenuhi oleh produksi impor (Agustina, 2015). Peningkatan produksi susu dalam negeri harus ditingkatkan demi memenuhi kebutuhan susu nasional. Untuk meningkatkan jumlah produksi susu dalam negeri, jumlah ternak sapi perah terus meningkat. Jumlah populasi sapi perah di Indonesia pada tahun 2014 sebanyak 444.226 ekor dan meningkat jumlahnya pada tahun 2015 sebanyak 525.171 ekor (BPS, 2015).

Pertumbuhan populasi ternak sapi perah PFH dipengaruhi oleh tingkat efisiensi reproduksi. Tinggi rendahnya efisiensi reproduksi pada ternak tergantung baik tidaknya pengelolaan reproduksi ternak (Hariadi dkk.,2011). Indeks fertilitas efisiensi reproduksi yang baik salah satunya ditentukan oleh jarak antar melahirkan (calving interval). Lamanya calving interval berpengaruh pada kandungan total solid yang terdapat dalam susu. Calving interval kurang dari 450 mempunyai kandungan total solid sebesar $12,89 \%$ sedangkan yang lebih dari 450 mempunyai kadungan sebesar 12,98\% (Baul et al., 2013).

Kandungan nutrisi dalam pakan untuk induk sangat berpengaruh dalam siklus birahi. Salah satu kandungan nutrisi pakan yang memperngaruhi reproduksi adalah protein. Protein pada pakan akan terdegradasi oleh mikroorganisme di dalam rumen melalui asam amino yang menjadi amonia dan asam lemak rantai bercabang (Guliński et al., 2016). Peningkatan kadar protein dalam pakan akan diikuti dengan kecernaan protein kasar yang lebih tinggi, sebagai akibat meningkatnya asupan protein yang dapat dicerna. Meningkatnya kecernaan diperkirakan memberi peluang adanya tambahan asupan nutrisi yang akan digunakan untuk pembentukan air susu (Broderick, 2003).

Protein merupakan suatu komponen yang mengandung unsur sulfur, fosfor, karbon, hidrogen dan unsur spesifik yaitu nitrogen (Hariadi dkk., 2011). Asupan protein adalah faktor yang paling penting menentukan 
produksi susu, komposisi susu, dan milk urea nitrogen (Guliński et al., 2016). Milk urea nitrogen merupakan hasil metabolisme protein pada sapi perah dan eksresi nitrogen urin (Jonker et al, 1998 dalam Nourozi et al, 2010). Milk urea nitrogen di atas $18 \mathrm{mg} / \mathrm{dl}$ menyebabkan penurunan sebesar $13 \%$ tingkat kesuburannya pada sapi perah dengan produksi susu 30-39,99 kg, tingkat kesuburan pada sapi perah akan lebih baik jika nilai kadar milk urea nitrogen 14-15,99\% (Nourozi et al, 2010). Pemeriksaan milk urea nitrogen dapat digunakan sebagai evaluasi terhadap kandungan protein dalam pakan sapi perah (Nousianen et $a l .$, 2004). Pemeriksaan kadar MUN pada sapi perah PFH di KUD Tani Wilis belum pernah dilakukan. Berdasarkan permasalahan di atas maka perludilakukan penelitian tentang kadar MUN di KUD Tani Wilis.

\section{Materi dan Metode Penelitian}

Materi yang digunakan dalam penelitian ini adalah 16 sapi PFH yang dibagi menjadi 2 kelompok yaitu: kelompok 1 terdiri 8 ekor sapi dengan calving interval kurang atau sama dengan 370 hari dan kelompok 2 yang terdiri dari 8 ekor sapi dengan calving interval lebih atau sama dengan 450 hari. Data calving interval diperkuat dengan melakukan survei lapangan berupa kuesioner kepada peternak tentang produksi susu dan pakan yang didasarkan pada pemilihan sapi perah periode laktasi. Teknik pengambilan sampel menggunakan purposive sampling. Sampel susu segar diambil masing-masing sebanyak $100 \mathrm{ml}$ yang diperoleh dari 16 sapi PFH.

\section{Analisis Data}

Data kadar milk urea nitrogen berdasarkan calving interval di uji dengan uji t.

\section{Hasil dan Pembahasan}

Data sebagai variabel kendali penelitian ini berupa produksi susu, pakan hijauan, dan konsentrat, dapat dilihat pada Tabel 2. Hasil yang didapat dalam penelitian ini adalah tidak adanya pengaruh kadar MUN berdasarkan calving interval yang berbeda. Antara kelompok I dengan kelompok II yang dikelompokkan berdasarkan calving interval $\leq 370$ dan $\geq 450$ mempunyai perbedaan yang tidak nyata $(p>0,05)$ terhadap kadar MUN. Banyak hal yang mempengaruhi panjang pendeknya calving interval. Skor kondisi tubuh, lama laktasi, maupun periode laktasi berpengaruh pada calving interval. Pada penelitian ini angka services per conception pada kelompok 1 yaitu 1 - 2 dan pada kelompok 2 mempunyai angka $3-4$.

Lama laktasi seekor induk sapi perah cenderung menghasilkan produksi susu yang tinggi (Prasetyo dkk.,2015). Hasil produksi susu yang tinggi pada sapi bergantung pada kandungan protein yang tinggi pada pakan (Nourozi et al., 2010). Katabolisme protein tubuh yang berlebih dapat berkontribusi dalam meningkatnya blood urea nitrogen (BUN). Kelebihan ini akan diserap didalam ginjal yang membentuk $\mathrm{N}$ dan dikonversikan menjadi urea di dalam liver, urea akan diekskresi menjadi urin (Roy et al.,2011). Ada sekitar 50\% dari kelebihan urea dikeluarkan bersama urin dari tubuh. Selain itu, sapi perah akan mengeluarkan sekitar 2,5-3 \% dari jumlah urea bersama susu (Spek, 2013).

Produksi susu yang optimal pada sapi perah direkomendasikan mempunyai kandungan protein dalam pakan sebesar $18 \%$ dengan hasil sekitar $30 \mathrm{~kg} /$ hari. Sapi dengan produksi susu sekitar $10 \mathrm{~kg} /$ hari hanya membutuhkan protein pakan maksimal $13 \%$. Produksi susu yang meningkat diperlukan konsentrat, kebutuhan konsentrat per hari mempunyai rasio 50:50 dengan hijauan (Ben Lukuyu dan Gachuiri, 2012). Pada penelitian ini konsentrat diberikan berupa protalis yang jumlahnya \pm 25\% dari jumlah total kebutuhan pakan setiap hari. Protalis diproduksi oleh KUD Tani Wilis, kandungan proteinnya sekitar 16-18 \% dan Total Digestible Nutrient (TDN) sekitar 69$70 \%$.

Pada penelitian ini ingin diketahui kadar MUN pada sapi perah PFH berdasarkan calving interval yang berbeda. Pada sapi perah, tingkat kesuburannya akan lebih baik jika nilai kadar milk urea nitrogen 14-15,99\% (Nourozi et al, 2010), sedangkan sapi yang mengalami gangguan pada reproduksinya mempunyai kadar diatas 18 mg/dl (Nourozi et al, 2010). Pada penelitian ini didapatkan hasil MUN kelompok I dengan rata-rata $10,44 \pm 4,51$ dan 
Tabel 1. Calving interval dan MUN (rata-rata \pm SD) sapi perah PFH di KUD Tani Wilis.

\begin{tabular}{|c|c|c|}
\hline Parameter & Kelompok I & Kelompok II \\
\hline Calving Interval (hari) & $355,63^{\mathrm{a}} \pm 15,91$ & $473,75^{\mathrm{b}} \pm 34,20$ \\
\hline MUN & $10,44 \pm 4,51$ & $9,25 \pm 2,75$ \\
\hline \multicolumn{3}{|c|}{$\begin{array}{l}\text { dan b: Superskrip yang berbeda pada baris yang sama menunjukkan perbedaan yang nyata } \\
(\mathrm{p}<0,05) \text {, kelompok I : sapi dengan calving interval } \leq 370 \text { hari, kelompok II, sapi dengan } \\
\text { calving interval } \geq 450 \text { hari ; ulangan } 8 .\end{array}$} \\
\hline 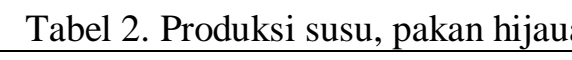 & onsentrat (rat & di KUD Tani Wil \\
\hline Parameter & Kelompok I & Kelompok II \\
\hline Produksi Susu (liter/ekor/hari) & $14,13 \pm 4,88$ & $15,25 \pm 3,88$ \\
\hline Pakan Rumput Gajah (kg/ekor/hari) & $32,50 \pm 8,86$ & $36,25 \pm 2,31$ \\
\hline Protalis (kg/ekor/hari) & $8,13 \pm 2,36$ & $7,38 \pm 1,19$ \\
\hline
\end{tabular}

Keterangan : Tidak berbeda nyata.

kelompok II dengan rata-rata $9,25 \pm 2,75$, angka tersebut masih dibawah rata-rata sapi yang mempunyai kesuburannya baik. Pada penelitian ini calving interval yang berbeda tidak mempunyai perbedaan terhadap kadar MUN.

\section{Kesimpulan}

Berdasarkan penelitian yang telah dilakukan dapat disimpulkan bahwa kadar milk urea nitrogen (MUN) tidak menunjukkan perbedaan pada calving interval yang berbeda.

\section{Daftar Pustaka}

Agustina, T. 2015. Outlook Komoditas pertanian Sub Sektor Peternakan Susu. Pusat Data Dan Sistem Informasi Pertanian. Sekretariat Jenderal Kementrian Pertanian. Jakarta.

BadanPusatStatistik. JumlahPopulasiSapiPerah 2009 - 2016. www.bps.go.id.[ 2 Januari 2017].

Baul, S., L-T. Cziszter, S. Acanticai, T. Cismas, S. Erina, D. Gavojdian, I. Tripon, and G. Buzamat. 2013. Effect of Calving Interval on Milk Yield and Quality Evolution during Lcatation in Dairy Cows. Scientific Papers: Animal Science and Biotechnologies. 46: 289-293.

Broderick, G.A. 2003. Effect of Varying Dietary Protein and Energy Levels on the Production of Lactating Dairy Cows. J. Dairy Sci. 86: 1370-1381.
Guliński, P.,E. Salamańczyk, and K. Mlynek. 2016. Improving Nitrogen Use Efficiency Of Dairy Cows In relation To Urea In Milk - A Review. Animal Science Papers And Reports. 34: 5-24.

Hariadi, M., S. Hardjopranyoto, Wurlina, H.A. Hermandi, B. Utomo, Rimayanti, I. N. Triana, dan H. Ratnani. 2011. Ilmu Kemajiran Pada Ternak. Departemen Reproduksi Veteriner. Fakultas Kedokteran Hewan. Universitas Airlangga.

Lukuyu, B. and C. Gachuiri. 2012. Feeding Dairy Cattle In East Africa. East Africa Dairy Development Project. International Livestock research Institute. Kenya.

Nourozi, M., A. H. Mousavi, M. Abazri, and M. R. Zadah. 2010. Milk Urea Nitrogen and Fertility in Dairy Farms. J. Of Animal and Veterinari Advances 9: 1519-1525.

Nousianen, J., K. J. Shingfield, and P. Huhtanen. 2004. Evalution Of Milk Urea Nitrogen As A Diagnostic Of Protein Feeding. J. Diary Sci. 87: 386-398.

Prasetyo, Y., M. Hartono, dan Siswanto. 2015. Calving Interval Sapi Perah Laktasi Di Balai Besar Pembibitan Ternak Unggul Dan Hijauan Pakan Ternak (BBPTU) Baturraden Purwokerto Jawa tengah. Jurnal Ilmiah Peternakan terpadu. 3: 7-14.

Roy, B., B. Brahma, S. Ghosh, P.K. Pankaj and G.Mandal. 2011. Evalution of Milk Urea Concertation as Useful Indicator for Dairy Herd Management: A review. Asian 
Journal of Animal and Veterinary Advances. 6: 1-19.

Spek J.W., 2013. A study on factors that affect the relationship between milk urea concertation and cow fertility. $\mathrm{PhD}$ Thesis.

Wageningen University. 1-162. 